\title{
COMPREHENSIVE EVALUATION OF DIFFERENT TILLAGE SYSTEMS FOR SUGAR BEET PLANTING
}

\section{Dina Refat Mohamed ${ }^{1}$, Samy Mohamed Younis ${ }^{2}$ and Abdel all Zaki Taieb ${ }^{3}$}

\section{ABSTRACT}

Experiments were conducted in the agricultural experiments station, Faculty of Agriculture, Cairo University at Giza. Three soil tillage systems were identified. The first system consisted of chisel plough followed by disc harrow, the second system consisted of mouldboard plough followed by disc harrow while the third system consisted of disc plough followed by disc harrow). The area was divided into 27 plots to test the performance of the three tillage systems, while working at three forward speeds and three ploughing depths. The comprehensive analysis of the studied physical and technical parameters led to the conclusion that the chisel plough provided the suitable seed bed at highest rate of performance and lowest specific energy consumption when executing the soil moving operation at $6 \mathrm{Km} / \mathrm{h}$ speed and at $10 \mathrm{~cm}$ depth.

\section{INTRODUCTION}

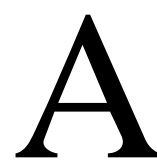
gricultural soil movement results from farmer's attempts to change prevailing soil conditions and properties to those that are more suitable for growing crops. Soil dynamics primarily includes soil tillage tool relations. Advances in soil tillage research since the sixties have indicated that it is a fully recognized area of research. There are many group of variables entering into soil tillage studies for use in obtaining more suitable soil conditions. The interaction among these variables and factors constitute cause and effect the relationships.

Yousif (2011) found that increasing forward speed of the tillage equipment increased the soil porosity and decreased the bulk density. Penetration resistance showed an increasing trend correlated with increasing depth of ploughing. This behavior was found in the studies of AL-Hashem et al (2009), Abdel Galil (2007) and EL- Sharabasy (2005).

\footnotetext{
1- MSC student. Agric . Eng . Dept.fac. of Agric,CairoUniv.

2- Professor, Agric . Eng . Dept Fac.of Agric,Cairo Univ.

3- Associate Professor, Agric . Eng . Dept. Fac.of Agric,Cairo Univ.
} 
Many researchers have been interested in studying the effect of the design of the working elements of the tillage equipment on the objective of the tillage operation. Morad (2012) tested a combination machine for seed bed preparation and analyzed the effect of forward speed on the properties

Abo-Amera (2004) compared between the performance of fixed and vibrated chisel plough shanks . Better values of soil porosity and mean weight diameter of soil aggregates were achieved with vibrated shanks. It is obvious that field capacity changes proportionally with the working speed and consequently specific energy consumption follows a decreasing tend. These effects were found in the studies of Abo-Habaga et al (2010), Abdel - Galil (2007) and Khadr (2004). Hammed (2001) concerned with sugar cane, found that using chisel plough in $30 \mathrm{~cm}$ before disc harrow recorded the highest values of bulk density and lowest value of penetration resistance but yield data showed that chisel plouging to depths of 20 and $30 \mathrm{~cm}$ before disk harrow significantly increased cane and sugar yield .The highest field productivity was obtained with the combined disc harrowing and $20 \mathrm{~cm}$ chisel ploughing sugar yield per hectare increased by 1 metric ton which was 8-6\% higher than that of conventional method ( disc harrowing only).

The current research represents a continuated approach in studying soil tillage equipment relations towards suitable seed bed for sugar beet crop . This aim is planned to be realized through comprehensive evaluation of different tillage systems in the view of their effects on soil behavior which will be inherent in the analysis that describes the soil behavior providing a basis for characterizing soil with regard to its change after tillage.

\section{MATERIALS \& METHODS}

Three soil tillage systems were identified in terms of their influence on the properties of soil and on their technical characteristics. The first system consisted of chisel plough followed by disc harrow the second system consisted of mouldboard plough followed by disc harrow while the third system consisted of disc plough followed by disc harrow.

The technical specification of the tested equipment are presented in table (1). 
Table (1) Technical specifications of the tillage equipment

\begin{tabular}{|c|c|c|c|c|}
\hline characteristics & $\begin{array}{c}\text { Chisel } \\
\text { plough }\end{array}$ & $\begin{array}{c}\text { M.B } \\
\text { plough }\end{array}$ & $\begin{array}{c}\text { Disk } \\
\text { plough }\end{array}$ & $\begin{array}{c}\text { Disk } \\
\text { harrow }\end{array}$ \\
\hline Source of manufacture & Local & Local & Local & Local \\
\hline The working width & $192.5 \mathrm{~cm}$ & $201 \mathrm{~cm}$ & $186 \mathrm{~cm}$ & $160 \mathrm{~cm}$ \\
\hline The No of functional part & 7 & 3 & 3 & 10 \\
\hline $\begin{array}{c}\text { The spacing between } \\
\text { functional part }\end{array}$ & $55 \mathrm{~cm}$ & $67 \mathrm{~cm}$ & $62 \mathrm{~cm}$ & 16 \\
\hline
\end{tabular}

The tillage equipment were powered by agricultural tractor with the following specifications as shown in table (2).

Table (2) Technical specifications of the Agricultural tractor

\begin{tabular}{|c|c|}
\hline characteristics & The tractor \\
\hline Source of manufacture & Rwasia \\
\hline Model & Bela raus \\
\hline System of drive engine & $2 \mathrm{WD}$ \\
\hline Engine hp & 80 \\
\hline
\end{tabular}

Experiments were conducted in the agicultural experiments station, Faculty of Agiculture, Cairo University at Giza.

The total Experimental area was $3600 \mathrm{~m} 2$ (0.857 feddan). The area was divided into 27 plots to test the performance of the three tillage systems ,while working at three forward speeds and three ploughing depths. The plan of performing the field experiments is described in this plan .

\section{Plan of the field experiments}

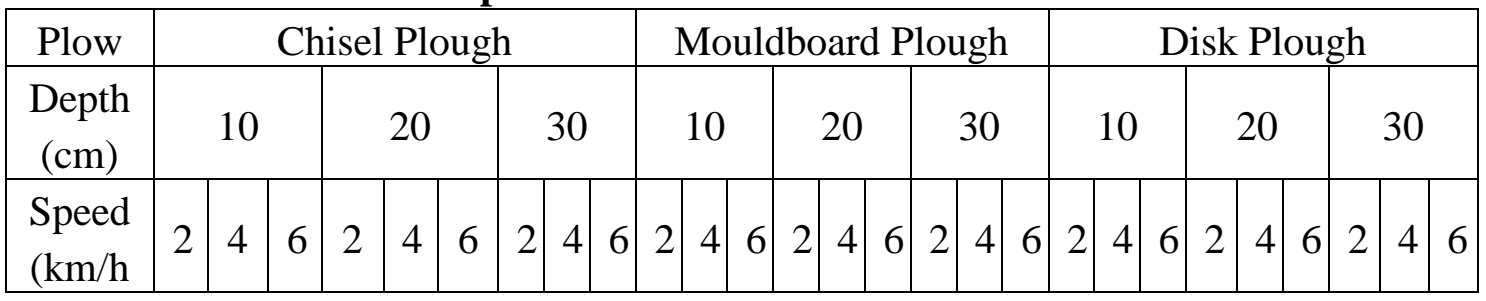

The prevailing conditions limit the area of each combined variables (depth - speed) to be $\left(18 \mathrm{~m}^{*} 100 \mathrm{~m}\right)$ in using chisel plough and $(9 \mathrm{~m} * 100 \mathrm{~m})$ in using moldboard and disk plough

In each trial two groups of parameters were considered. Agronomical parameters are related to soil properties to check to what extent an 
improvement in the soil -air-water complex is realized due to the movement of soil by applying each tillage system . The chosen technical parameters describe the performance of different equipment during executing the mechanized field operations .Each parameter depends on some basic components which were measured in the field.

\section{Agronomical parameters}

Samples of the soil of the experimental area of each trial before and after the tillage were analyzed to indicate the following properties and constitute cause and effect relation.

1- Type of soil :-

Mechanical analysis indicated the type of soil clay loom soil.

2- Bulk density:-

The undisturbed core method was used to calculate the soil bulk density, the following equation was applied:-

$\mathrm{Pd}=\mathrm{Ms} / \mathrm{Vt}$

Pd: dry bulk density $\left(\mathrm{g} / \mathrm{cm}^{3}\right)$.

Ms: the mass of dry soil $(\mathrm{g})$.

$\mathrm{Vt}$ : the total volume of soil $\left(\mathrm{cm}^{3}\right)$.

3- Porosity :-

The following equation was applied:-

$=1-($ soil bulk density/soil real density $) \times 100$

\section{Technical parameters}

1- Calculation of total time :-

$=$ the time of tillage + the lost time $(\mathrm{h} / \mathrm{fed})$

2- Actual field capacity:-

$\mathrm{AFC}=1 /$ total time

(fed / h)

3- Average fuel consumption :-

The fuel tank was filled with fuel before starting the field operation .After performing the assigned area the fuel tank was refilled and the added quanfity of fuel was measured by means of graduated cylinder. The warked area and the consumed time of work were measured and recorded

= consumed fuel volume / fuel consumption time

(lit / h) 
4- Specific energy consumption :-

$=(\mathrm{Fc} / 3600) \times \mathrm{P}_{\mathrm{f}} \times \mathrm{C} . \mathrm{V} \times 427 \times \mathbf{n}_{\mathrm{th}} \times \mathbf{n}_{\mathrm{m}} \times(1 / \mathrm{AFC}) \times(1 / 75) \times$ $(1 / 1.36) \quad(\mathrm{kW} . \mathrm{h} / \mathrm{fed})$

Where:

Fc : Fuel consumption rate $(\mathrm{L} / \mathrm{h})$

$\mathrm{P}_{\mathrm{f}}$ : Density of fuel ( for diesel oil $=0.85 \mathrm{~kg} / \mathrm{L}$ )

C.V: colorific value of fuel $=10000 \mathrm{Kcal} / \mathrm{kg}$

427 : Thermal mechanical equivalent ( $\mathrm{kg} . \mathrm{m} / \mathrm{kcal}$ )

$\mathbf{n}_{\text {th }}$ : Thermal efficiency of engine assumed $40 \%$ for diesel engine

$\mathbf{n}_{\mathrm{m}}$ : Mechanical efficiency of engine assumed $80 \%$ for diesel engine.

AFC : Actual field capacity ( fed /h).

\section{RESULTS \& DISCUSSION}

Mechanical analysis of experimental soil indicated that the soil texture of the experiment was clay loom.

Effect of tillage systems on the physical properties of soil .The measured values of the properties of soil after moving the soil due to the effect of the three tillage systems are presented in figure (1). Soil bulk density of the soil followed an decreasing tend with increasing forward speed at the three working depths. While when the plough worked at the same speed and penetrated the soil deeper and deeper the soil bulk density increased, as the soil layers are subjected to an increased compaction. Soil porosity changed oppositely compared with bulk density due to changing the working speed of ploughing depth. This is explained as a result of changing the area of the moved soil by increasing the working depth. Similar trend is noticeable for the performance of the turning ploughs.

The optimum values of bulk density and Porosity of the seedbed prepared by the three tested tillage systems are found at $6 \mathrm{~km} / \mathrm{h}$ working speed and at $10 \mathrm{~cm}$ depth.

Effect of working conditions on the technical parameter of the tillage systems.

The Technical parameter described the performance of different tillage equipment during executing the soil moving operations are the following:- 

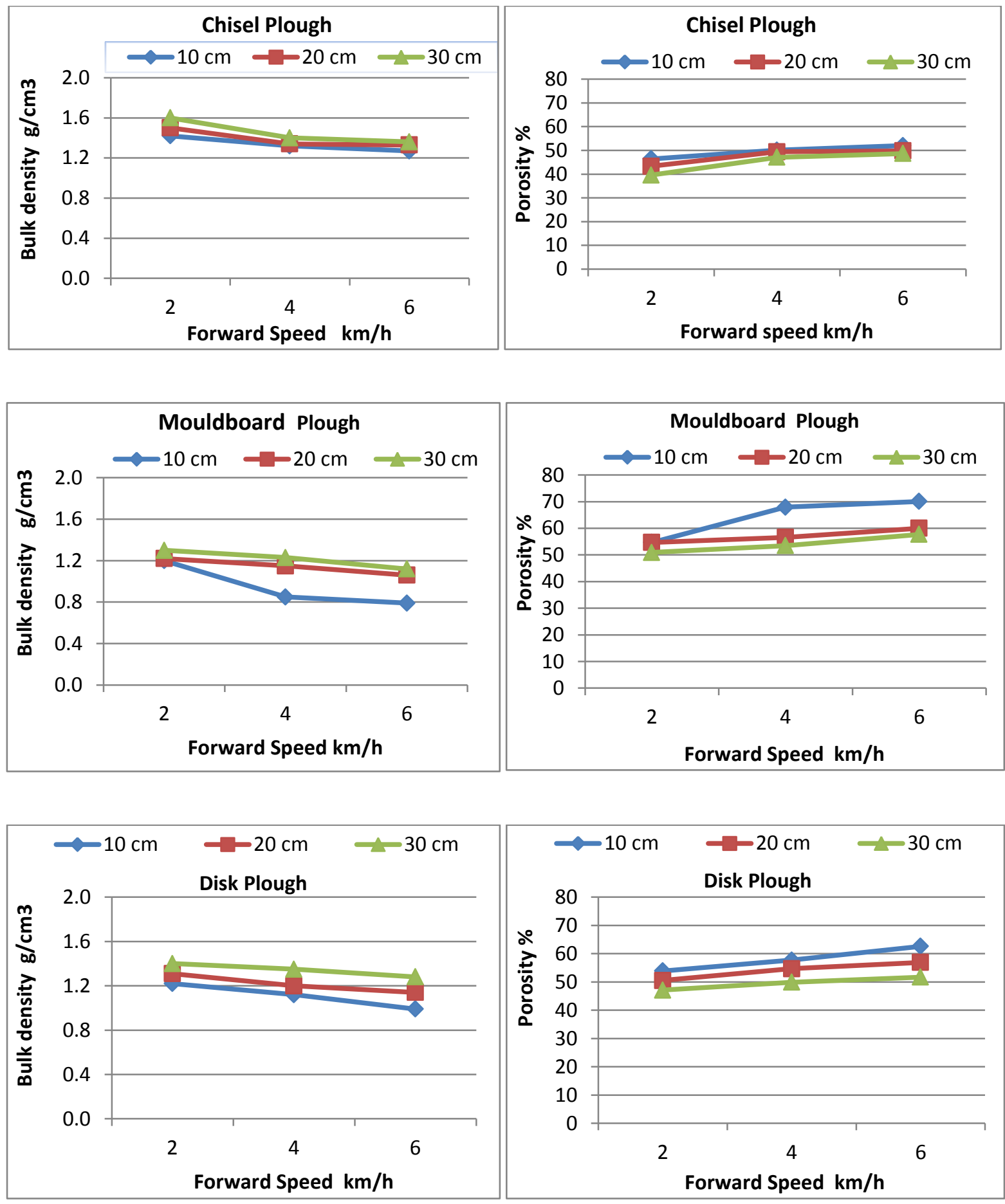

Fig ( 1) : Effect of tillage system on physical properties of soil 


\section{1- Actual field capacity :-}

This parameter differentiates between the rate of performance of each equipment as affected by working speed at the three depths. Figure (2) shows that the actual field capacity increased as the working speed increased. The rate of increase differs among the three ploughs. This may be due to the different working width of each plough.
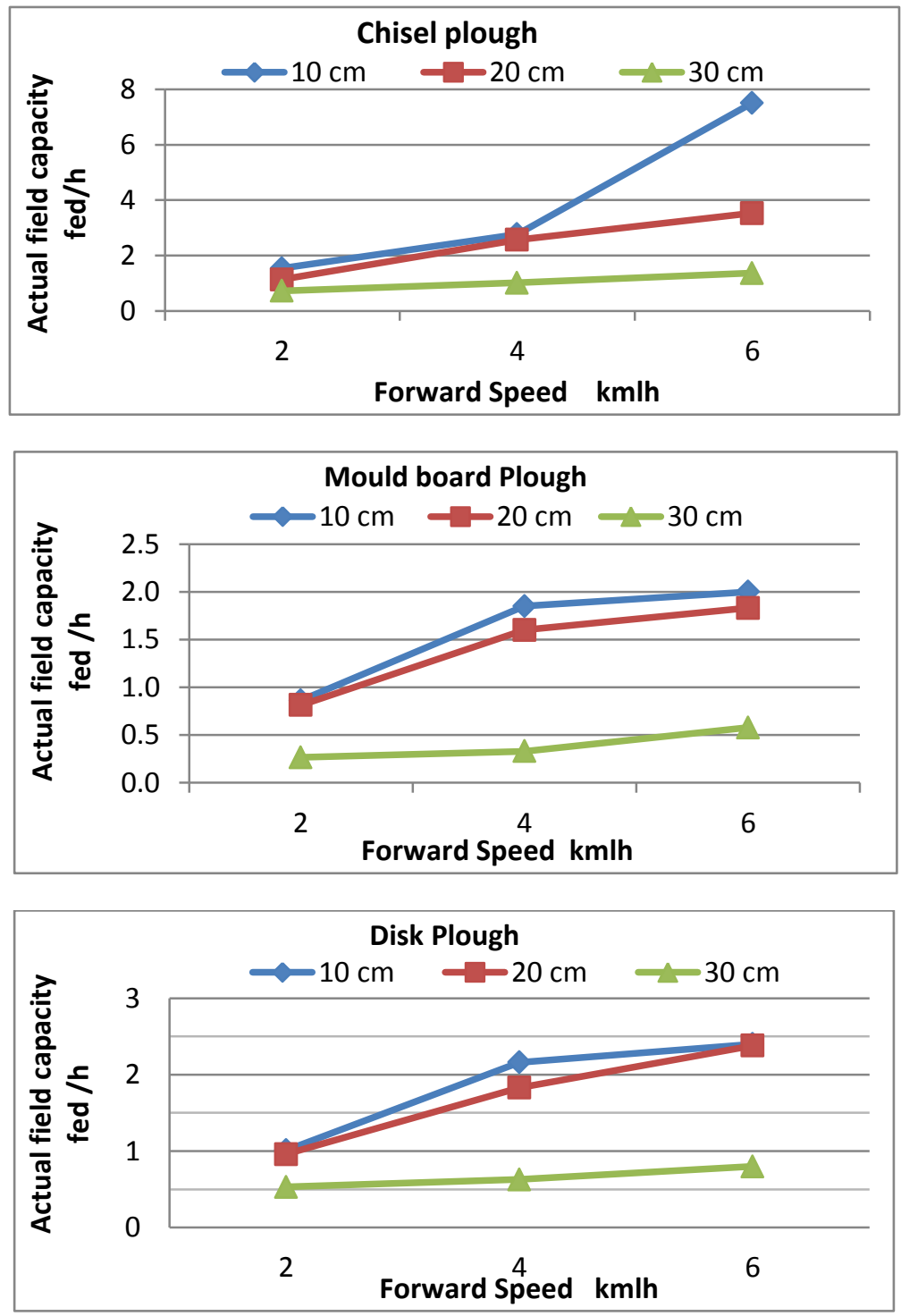

Fig (2) : Effect of tillage systems on the field capacity 
Concerning the ploughing depth at the same working speed the rate of performance decreased as each plough tilled the soil at greater depth. Moving the soil in this case consumed more energy and on behalf of the rest available energy to keep uniform speed to realize the same rate of performance.

\section{2- Specific energy consumption:-}

The two affecting working conditions played an important role in determining the amount of the consumed fuel. As the forward speed increased the volume of the burnt fuel increased. The mouldboard plough consumed the highest volume of fuel followed by the disc plough and the lowest fuel consumption was for the chisel plough. This trend was remarked for the different speeds and depths. The function of the mouldboard plough as it provides complete turning of the cut slice may justify the increased amount of fuel.

On the other hand, reviewing the realized actual field capacity by the three ploughs and incomparating its values with the fuel consumption gave more clear idea about the different technical performance of the primary soil moving equipment.

Specific energy consumption was calculated and plotted at different speeds and depths in figure (3).

Both the rate of fuel consumption and actual field capacity increased with increasing the forward speed, but the increased amount of consumed fuel did not over come the increased rate of performance This situation explains why the specific consumed energy decreased by increasing the working speed . Opposite finding were calculated and revealed the cause of increasing the specific energy consumption with increasing the plowing depths.

The comprehensive analysis of the studied physical and technical parameters lead to the conclusion that the chisel plow provided the suitable seed bed at highest rate of performance and lowest specific energy consumption when executing the soil moving operation at $6 \mathrm{Km} / \mathrm{h}$ speed and at $10 \mathrm{~cm}$ depth. 

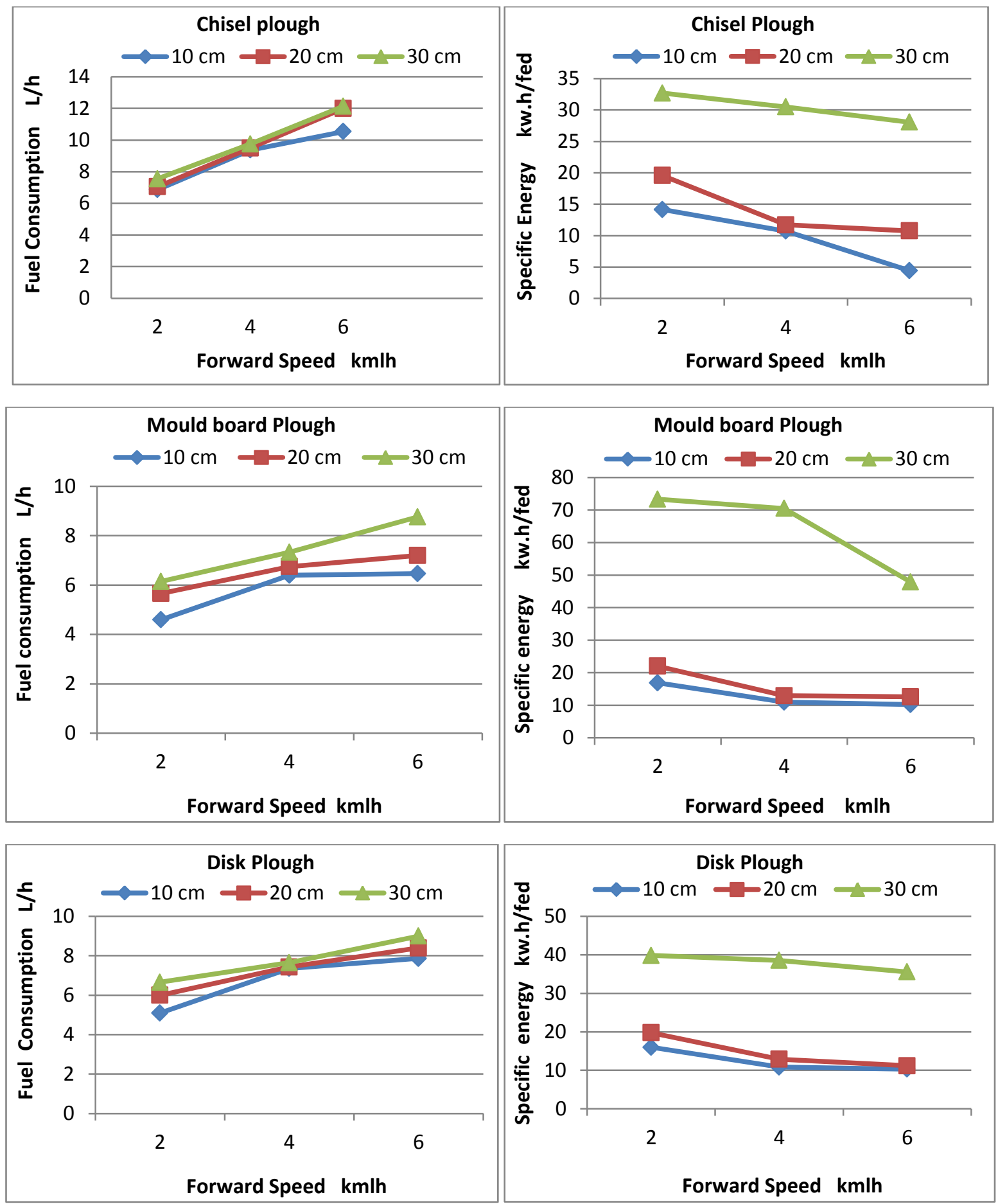

Fig (3) : Effect of tillage systems on the energy consumption. 


\section{SUMMARY}

Agricultural soil movement results from farmer's attempts to change prevailing soil conditions and properties to those that are more suitable for growing crops. Advances in soil tillage research since the sixties have indicated that it is a fully recognized area of research.

The current research represents a continuated approach in studying soil tillage machine relations towards suitable seed bed for sugar beet crop.

Three soil tillage systems were identified in terms of their influence on the properties of soil and on their technical characteristics. Chisel mouldboard, and disk ploughs each followed by disc harrow constituted the three soil tillage systems .Experiments were conducted in the agricultural experiments station, Faculty of Agriculture ,Cairo University in a clay Loam soil. Three working speeds and three plowing depths were tested.

Bulk density and porosity indicated the soil behavior while field capacity, specific energy consumption measured the technical evaluation parameters

The obtained results revealed that the optimum values of bulk density and porosity at using the three tillage systems were the effect of performing tillage operations at $6 \mathrm{~km} / \mathrm{h}$ and $10 \mathrm{~cm}$ depth. The mouldboard plow caused the best values of these two parameters advantageous to chisel and disk plows. Concerning technical parameters, the chisel plow realized the highest field capacity and consumed the least amount of fuel to realize the lowest specific energy consumption.

The comprehensive evaluation was to the chisel plow which can be recommended to prepare the more suitable seedbed for planting sugar beet.

\section{REFERENCES}

Abdej-Galil, H. S, (2007) Effect of using rotary plow on soil physical properties and barley yield under rain fall conditions. Misr J. Ag. Eng; 24(4): 666-687

Al-Hashem, H. A. S, (2009) Comparision of the performance of the chisel plow and the subsoiler on sandy soils and there effect on barley 
production (In Arabic with English summary). J. Agric. sci Monsoura Univ.; 34(4):4031-4042

Aboamera, M. A , M. A. Abd El maksoud, A. S. El-Kot, and A. A. Meslhy (2009) Effect of vibratory chisel plow on power requirements and soil physical properties. Minufiya .J; Agric .Res. Vol 34 No $2: 525-547$.

Abo-Habaga, M. M., Kh. A. A. Khadr, and O. E. M. M. Naeem, (2010) Energy requirements for operating the rotary plow under Egyptian conditions. J.soil. sci.and agric.Eng.Mansoura .uni . vol . 1(5):463473.

El-sharabasy, M.M.A and ,A.M.M.Ali , (2005) Study on some operating parameters affecting rotary plough performance under Egyptian condition. Misr J. Ag. Eng.; 22(2):335-350.

Gassem, A. A, K. M. Al-Kazaz and, M. S. Naoom (2006) Effect of irrigation systems and primary and secondary tillage on soil physically properties and corn yield. Annual conference of the Misr Society of Ag.Eng:1190-1203

Jebur, H. A, (2008) The effect of soil moisture and primary plows on some performance properties and total costs. (In Arabic with English summary). Misr J. Ag. Eng. 25(4): 1310-1322.

Khadr, K. A. A., (2004) Energy requirement for some seed bed preparation implements under Egyptian condition. Misr Society of Agr. Eng.:481-491.

Morad, M. M, M. M. Ali, (2012) Manufacture and evaluation of a combination machine for seed bed preparation, water harvesting and planting under rainfed acricultural conditions.MisrJ.Eng,29(4):1437-1456.

Said, H. M. (2003) Effect of tillage implement on the state of compaction in different soils. Egypt J. Soil. Sci. 43.No1:91-107. 
Yousif , H. S., (2011) Mechanization of seedbed preparation for sesame crop production. MSc. Thesis, Faculty of Agric. Cairo Univ. :101 P.

الملخص العربي

التقيم الثامل لانظمة الحرث المختلفة لزراعة بنجر السكر

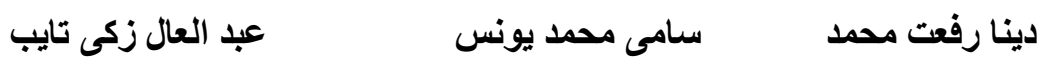

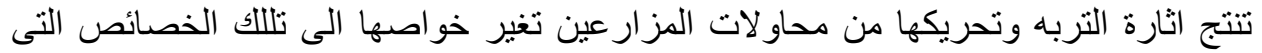
تناسب نمو محاصيلهر ـ ومنذ عقود طويله وحتى الان ماز الت البحوث المتعلقة باثارة التربة تمثل التل مجالا و اسعا للبحوث و النطوير.

يعتبرهذا البحث استمر ارا لاجتهادات الباحثين حيث يدرس العلاقة بين التربة والة الاثارة لاعداد

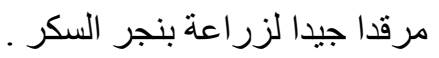

تحددت ثنلاث نطم لاثارة التربة تتكون من محر اث حفار ومحر اث قلاب مطرحى ومحر اث قلاب

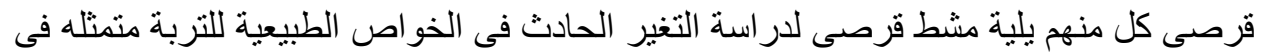
الكثافة الظاهرية و المسامية و على الجانب الاخر اختيرت السعة الحقلية لوحده الاثارة والاستهلاك النو عى للطاقة ليقيما الاداء الفنى للالاته

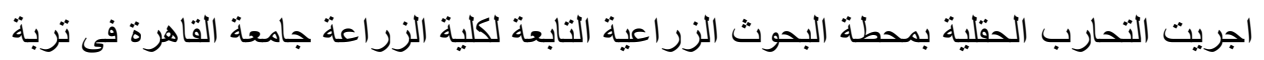

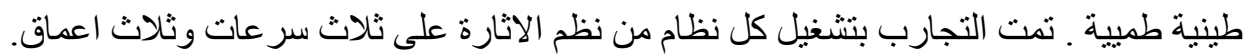

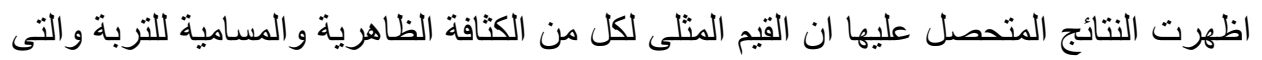

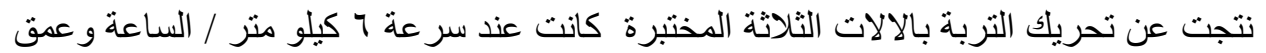

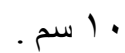

وحقق المحراث القلاب المطرحى احسن قيم لهاتين الخاصيتين متفوقا على كل من المحراث

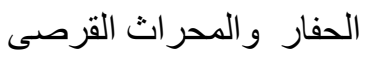

الدحر اث الحفار انجز اكبر سعة حقلية واستهلك اقل كمية من الوقود وبذللك كانت الطاقة النوعية

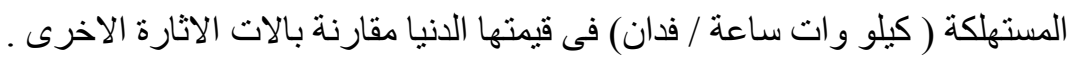

وبالتقيم الثامل للاداء الفنى للالات المختبرة يمكن التوصية باستخدام المحر اث الحفار كألة اثارة

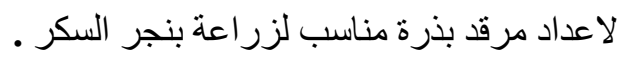

